\title{
HUMAN CELL THERAPY FOR VENOUS LEG ULCERS
}

\author{
Herbert B. Slade1, ${ }^{1,2}$ Nasreen Jacobson ${ }^{1,3}$, Yiling Lư ${ }^{1,3}$ \\ 'Smith \& Nephew, Inc., Fort Worth, Texas, USA \\ ${ }^{2}$ Department of Pediatrics, University of North Texas Health Sciences Center, Texas, USA \\ ${ }^{3}$ Department of Biomedical Sciences, University of North Texas Health Sciences Center, Texas, \\ USA
}

\begin{abstract}
Non-healing, chronic venous leg ulcers are sometimes mistakenly described as acute wounds that progress from hemostasis to inflammation but then become stuck in the inflammatory phase of healing. Typical explanations for this include colonization by bacteria, tissue infection, or the formation of bacterial biofilms. When standard care with debridement and compression bandaging fails to promote healing, therapeutic approaches shift to more aggressive surgical debridement, antimicrobial therapy, and the use of biological dressings or autologous grafts. A pathophysiologic view of persistent venous hypertension reveals the primary role of dermal inflammation, leading eventually to skin ulceration in a manner distinctly different from an acute wound. Subsequent to ulceration, additional inflammatory responses to invading pathogens can become important, but the underlying inflammatory state must be controlled before healing can take place, even with the use of skin grafts or cultured autologous skin cells. The prior belief that allogeneic keratinocytes and fibroblasts could engraft has given way to a more sophisticated consideration of the immunologic interplay between inflamed tissue and applied cells. This review briefly summarizes the history of cell therapy for venous leg ulcers, with a focus on concepts that have been tested in clinical trials, and a consideration of future development approaches.
\end{abstract}

Key words: transplantation, tissue engineering, chronic venous insufficiency, venous ulcer, allogeneic.

\section{REVIEW PAPER}

Phlebological Review 2015; 23, 2: 29-38

DOl: $10.5114 /$ pr.2015.54032

Submitted: 01.06.2015

Accepted: 05.08.2015

\section{ADDRESS FOR CORRESPONDENCE}

Dr Herbert B. Slade

Department of Pediatrics, University of North

Texas Health Sciences Center

Texas, USA

e-mail: bert.slade@smith-nephew.com

\section{INTRODUCTION}

The focus of this review is on informative academic and industrial research into cell-based therapies for venous leg ulcers (VLU), with an emphasis on concepts that have been subjected to at least one controlled clinical trial (Table 1). Reasons for clinical or industrial failure are considered, together with hypotheses that may inform ongoing efforts to generate therapeutically meaningful products.

The motivation for attempting to develop "off-theshelf" cellular therapy for non-healing VLU stems from the cost, potential morbidity, and lack of uniform efficacy associated with autografting [1]. While individual surgeons may have a high success rate with good debridement and grafting, a cell-based approach that is more predictable and less dependent on surgical skill and judgment is desirable, particularly for cases that have failed prior therapy or involve substantial tissue loss. Trials reported in the literature are of variable quality, which introduces a degree of uncertainty when comparing results. It is important for VLU study protocols to require accurate confirmation of the ulcer etiology, ide- ally through visualization of venous reflux using duplex Doppler with augmentation and probe compression to test for thrombi. Plethysmography may substitute where Doppler examination is unavailable. The contribution of venous ablation to ulcer healing remains unclear [2], but it should be noted whether ablation has been performed.

Several reviews have been published elsewhere covering the full history of cell-based therapies for skin loss $[1,3-5]$, including an excellent review focused on tissueengineered products [6].

\section{INJURY AND REPAIR - VENOUS LEG ULCERS}

Acute skin injuries that are limited to the epidermis or superficial dermis will heal quickly with a full return to the pre-injury state. This encourages the belief that appropriate therapeutic intervention(s) might allow all degrees of skin injury to resolve with a full regeneration of original tissue structure and function. Efforts towards creating such therapies are equally inspired by the disfiguring scarring and loss of function seen in full thickness burn injuries. Progress in cell therapies for VLU has been somewhat slower than for burns, in part because the role 
Table 1. Academic and industrial cell-based products for which at least one randomized clinical trial has been reported in patients with venous leg ulcers

\begin{tabular}{|c|c|c|c|c|c|c|c|c|c|}
\hline & \multicolumn{3}{|c|}{ Autologous } & \multicolumn{6}{|c|}{ Allogeneic } \\
\hline & Skin graft & BioSeed S & EpiDex & Celaderm & Cyzact & Dermagraft & Apligraf & HP802 & OrCel \\
\hline \multicolumn{10}{|l|}{ Cells } \\
\hline Keratinocytes & $\checkmark$ & $\checkmark$ & $\checkmark$ & $\checkmark$ & & & $\checkmark$ & $\checkmark$ & $\checkmark$ \\
\hline Fibroblasts & $\checkmark$ & & & & $\checkmark$ & $\checkmark$ & $\checkmark$ & $\checkmark$ & $\checkmark$ \\
\hline Other & $\checkmark$ & & t & & & & & & \\
\hline Expanded ex vivo & & $\checkmark$ & $\checkmark$ & $\checkmark$ & $\checkmark$ & $\checkmark$ & $\checkmark$ & $\checkmark$ & $\checkmark$ \\
\hline \multicolumn{10}{|l|}{ Matrix } \\
\hline No matrix & & & $\checkmark$ & & & & & & \\
\hline Biosynthetic & & $\checkmark$ & & & & $\checkmark$ & & & \\
\hline Biologic & $\checkmark$ & $\checkmark$ & & $\checkmark$ & $\checkmark$ & & & $\checkmark$ & \\
\hline Xenogeneic & & & & & & & $\checkmark$ & & $\checkmark$ \\
\hline \multicolumn{10}{|l|}{ Format } \\
\hline Fresh & $\checkmark$ & $\checkmark$ & $\checkmark$ & & $\checkmark$ & $\checkmark$ & $\checkmark$ & & \\
\hline Frozen & & & & $\checkmark$ & & & & $\checkmark$ & $\checkmark$ \\
\hline VLU Trials ${ }^{\dagger \dagger}$ & $\mathrm{CE}+$ & RCT+ & RCT+ & RCT- & RCT- & RCT- & RCT+ & RCT+ & RCT- \\
\hline \multirow{2}{*}{$\begin{array}{l}\text { Approved (VLU) } \\
\text { Marketed }\end{array}$} & N/A & Yes & Yes & No & No & No & Yes & No & No \\
\hline & $\mathrm{N} / \mathrm{A}$ & No & No & No & No & Yes & Yes & No & Yes \\
\hline
\end{tabular}

${ }^{\dagger}$ mesenchymal stem cells; ${ }^{+t}+(+)$ indicates that efficacy was clearly established, $(-)$ indicates that efficacy was not clearly established; $R C T$ - randomized controlled trial, CE - clinical experience

of cells in VLU has not been understood any differently from burns. The ability of viable autologous cells to replace missing tissue, combined with the hope that allogeneic cells could engraft, has kept the focus of product development on ex vivo reconstruction, replacement, and convenience. Having learned eventually that even with successful healing, engraftment of non-self cells does not occur with the use of bioengineered tissue constructs, research questions are now directed at understanding living cells as a source of dynamic biotherapies that interact with the damaged tissue and the milieu. What do living cells accomplish that cannot be accomplished by acellular biological matrices?

Realizing the potential of cell therapy to promote regeneration requires an understanding of the pathophysiology of VLU. It is known that congenital, primary, or secondary impairment of venous return from the lower extremity leads to venous hypertension [7-9]. The distension of veins and convolution of capillaries caused by venous hypertension leads to extravasation of red blood cells (RBC) from subcutaneous and dermal capillary beds, causing an initial tissue inflammatory response mediated in part by the tetrapyrrole heme molecule [10]. Heme acts on endothelial cells causing upregulation of adhesion molecules and angiogenic factors such as ICAM-1 (intra- cellular adhesion molecule 1) and VCAM-1 (vascular cell adhesion molecule 1), E-selectin, P-selectin, and von Willebrand factor, leading to transendothelial migration of neutrophils into tissue. Induction of CXCL-8 (IL-8) further attracts neutrophils, while heme may also inhibit neutrophil apoptosis and thus prolong the generation of reactive oxygen species by these inflammatory cells. Heme is inadequately cleared from the tissue by hemopexin, with accumulation seen as hemosiderin staining. The combined actions of heme, ferric iron, PMN oxidative damage, and pro-inflammatory (M1-type) macrophages [11-13] leads eventually to destruction of the dermis and epidermis [14]. M1 macrophages are found throughout the ulcer bed $[11,15]$, where they seem to prevent fibroblasts from effectively healing the wound $[16,17]$. Periulcer dermis typically shows evidence of unsuccessful healing, with elevated levels of transforming growth factor $\beta$ (TGF- $\beta$ ) and deposition of collagen resulting in lipodermatosclerosis. While colonization of the exposed tissue by bacteria further stimulates the influx of PMN and M1 macrophages [18], thus adding to the inflammatory state, VLU are not acute wounds that become chronic by virtue of becoming "stuck in the inflammatory phase" of normal wound repair [19]. 
With the exception of efforts to control TNF- $\alpha$ [2022] and matrix metalloproteinases [23], there have been few attempts to directly address the inflammatory state as a means of supporting healing. There is a clear indirect anti-inflammatory benefit from the use of four-layer compression bandages, and a recognition that cellular (e.g. Apligraf) products seem to beneficially modulate inflammation [24]. It is very likely that allogeneic cell therapy needs to include an optimization of anti-inflammatory mechanisms in order to be successful, even if appropriate and sufficient growth factors are a key part of the healing mechanism.

\section{IMMUNOLOGIC CONSIDERATIONS}

Tissue inflammation driven by innate mechanisms is sufficient to prevent engraftment of autologous tissue, and adaptive immune responses add a further layer of complexity. From a product development perspective even autologous-engineered tissues can generate adaptive immune responses directed at matrix components and excipients such as trace amounts of antibiotics from cell culture. Bovine type I collagen is an example of a matrix component with the potential to generate new immune responses, although this has been reasonably well tolerated. Experience with bovine collagen implants indicates that immune-mediated hypersensitivity reactions occur in the range of $1 \%$ [25] to $3 \%$ of patients, with antibody responses developing in $\sim 10 \%$ [26]. In industrial manufacturing, antibiotics and similar excipients are diluted to levels that can be used safely, with newer closed system bioreactor methods offering the promise to eliminate antibiotic use entirely. Even with only minor reactions to weakly immunogenic substances, the use of excipients or matrix components with the potential to provoke immune responses needs to be well justified.

In the presence of a normal immune system, allogeneic skin cells do not engraft or persist. When intact allogeneic skin is placed into a wound, survival is limited to 1-2 weeks due to provocation of adaptive immune rejection $[27,28]$. Isolated keratinocytes and fibroblasts do not stimulate an adaptive rejection, and therefore have the potential to survive until they die through replicative senescence, or they may be rejected by innate mechanisms [29-31]. As with a bilayer skin allograft, allogeneic keratinocytes and fibroblasts express Class I major histocompatibility antigens (HLA-I) that are mismatched to the recipient. Unlike skin allografts, allogeneic cells applied in suspension have an advantage. Neither CD4+ nor CD8+ T-lymphocytes are likely to be involved in rejection due to the lack of constitutive HLA Class II expression by the allogeneic cells $[32,33]$.

Of particular interest is the observation that regulatory T-cells (Tregs) traffic to sites of chronic skin inflammation in order to suppress potential autoimmunity. These Tregs would shift the balance against generation of either antibody or T-cell mediated responses. In fact, recent large trials with allogeneic cells have found no generation of anti-HLA antibodies despite repeated application of mismatched cells into inflamed tissue. It is possible that allogeneic challenge acts to boost anti-inflammatory responses from Tregs as a consequence of the effect of the prevalent cytokine TGF- $\beta$ [34], which is understood to direct CD4+ T-cells towards anergy during antigen presentation [35]. Alloantigen challenge within a TGF- $\beta$ rich environment may induce the generation of new Tregs from anergic CD4 T-cells, resulting in local accumulation of IL-10, producing CD4 Treg of type 1 (Tr1 cells) and/ or TGF- $\beta$ producing Th3 cells [36]. Interleukin 10 would serve to further blunt alloantigen responses and inflammation, promoting macrophage phenotypic switching.

While they are alive, allogeneic keratinocytes and fibroblasts cooperate to elaborate the growth factor GM-CSF, which is reported to influence the switch from pro-inflammatory M1 macrophages to pro-resolving M2 macrophages $[37,38]$. If the allogeneic cells can be made to die through apoptosis, for example by exposing them to gamma irradiation damage, engulfment of the apoptotic cells by macrophages can also suppress inflammation and activate resolution [39]. Another potential mechanism involving specifically apoptotic cells is the release of prostaglandin E2 (PGE2), which has been found to influence wound healing in a mouse model [40].

This would need to be balanced by the potential for large numbers of dying allogeneic cells to stimulate M1 macrophages. Natural killer (NK) cells do not express cell surface receptors for antigens per se, but rather they express clonotypic stimulatory and inhibitory receptors that are specific for self HLA-I molecules. Killing by NK cells must be suppressed through engagement of the inhibitory receptors. In the case of HLA-I mismatched keratinocytes and fibroblasts, no inhibition takes place, and within the inflammatory milieu of the chronic wound some stimulation would be expected, leading NK cells to kill allogeneic targets [41].

\section{STEPWISE APPROACH TO HEALING}

Properly applied compression bandaging alters venous transmural pressure to limit distention and extravasation, in the absence of arteriovenous communication [42]. Edema is controlled, and if applied early enough, tissue inflammation and fibroblast dysfunction may be minimized [43]. The wound tissue should also be free of infection and of devitalized materials that may promote bacterial colonization or otherwise impede healing. Wound bed preparation, patient nutritional state, and the choice and application of dressings are all believed to influence the success of treatment. Patient compliance is important, as shown in the improved rates of healing obtained during controlled clinical trials. Despite the application of this algorithm, approximately $40 \%$ of 
VLUs fail to heal [44]. Factors observed to be associated with failure to heal include greater size, location of the wound on the ankle, and colonization with certain bacterial species [45]. Longer duration is statistically associated with poor response to treatment, but the reason for continuing failure to respond is elusive. Molecular studies and practical experience suggest that the wound edge or wound bed may need to be surgically revised in order to remove senescent cells and expose healthier tissue [46], but unpublished studies with enzymatic debriders indicate that healing can occur from the edges without the need for sharp surgical debridement, possibly due to an anti-inflammatory effect.

\section{CELL THERAPIES}

Attempts to manipulate skin in culture date to the $19^{\text {th }}$ century [47]. The idea of generating skin de novo from cells [48] was encouraged by the structural simplicity of the epidermis and superficial dermis, and the fact that major physiologic benefits (physical protection, control of fluid loss) could be achieved at the minor expense of altered pigment and possible lack of renewed adnexa. Advancements in keratinocyte culture methodology by Rheinwald and Green [49] made engineered autografts [50] and allografts [51] possible for VLU treatment more than 30 years later. The use of bovine collagen as a scaffold for dermal mimic [52] added a cost-effective means of improving the constructs. However, a lack of keratinization at the surface and the absence of blood vessels at the base were among the problems for early sheet grafts [53]. Research into the development of "tissue-engineered skin" continues today for the treatment of burn injuries, using the patient's own healthy cells as a starting material, with a goal to provide thermoregulation, microbial defense, moisture balance, mechanical protection, and wound repair, ideally having the additional properties of normal texture, pigmentation, and elasticity [54]. The observed lack of HLA-II antigen expression by cultured keratinocytes and fibroblasts suggested that allogeneic "living skin equivalents" could be engineered as a readily available treatment [55]. Sources of allogeneic cells range from organ donors to living neonatal or adult donors. Skin cells are mainly derived from neonatal foreskin and plucked hair follicles, while mesenchymal stem cells for non-homologous treatment can be derived from amniochorion or adipose vascular stromal fraction. All of the products described here were constructed with either keratinocytes alone, fibroblasts alone, or both of these cell types.

\section{AUTOLOGOUS CELL APPROACHES}

The use of cultured autologous cells allows for engraftment, but does not guarantee engraftment. There is individual variability in the ability of cells to be expanded ex vivo, and graft take of engineered autologous tissues depends on the state of the wound bed to the same degree as a split thickness graft. Transmission of unknown pathogens is a potential concern any time cells are grown under culture conditions. Keratinocyte sheets are typically less than 10 cells thick, making them difficult to handle without a dermis-like backing. Without special transport conditions, cultured autografts must be applied to the wound the same day they are lifted from culture. Even with low-temperature extended transport, the wound surface needs to be ready for application when the tissue is ready. The adherence of epidermal sheets to the wound surface can be poor, requiring great care in placement, dressings, and even the allowed activities of the patient. All autologous cultured dermal/epidermal tissues suffer from poor vascularization and the inability to replace skin appendages such as hair follicles, sebaceous glands, and sweat glands. Rete ridges do not become established for several years, if at all [56].

Autografting of isolated or cultured cells does not require that they be constructed into a tissue-like material. The simplest alternative to pinch grafting appears to be the ReCell ${ }^{\mathrm{TM}}$ system (Avita Medical, AU) in which $24 \mathrm{~cm}^{2}$ of tissue is enzymatically digested in 30 minutes to produce a spray covering $1,920 \mathrm{~cm}^{2}$. Keratinocytes, fibroblasts, Langerhans cells and melanocytes have been identified in the mixed cell suspension. The number of viable cells is unknown, and a new biopsy is needed to create each subsequent dose if the first does not result in re-epithelialization. A small randomized controlled trial for VLU is expected to be completed in late 2015. Autografting in high quantity can be achieved by cell expansion ex vivo. By taking the biopsy material into a tissue culture laboratory for several weeks, keratinocytes can be isolated and expanded to much higher numbers then applied to the wound as a simple suspension in fibrin sealant [57]. If cell banking is performed, additional doses can be generated on demand without further biopsies. This requires very high levels of quality control to avoid mix-up between different donors/patients and contamination. The time delay between harvesting the seed cells and delivering a cultured product has significantly limited the industrial prospects for this approach.

Differences in culture conditions and the use of various dermal components may account for differences in reported efficacy across the various single-cell and multi-cell autologous tissue constructs, but generally good results have been obtained using basic engineered tissue approaches [58-61]. Despite the observed efficacy, efforts to industrialize autologous cell products have been generally unsuccessful. CellActiveSkin ${ }^{\mathrm{TM}}$ (IsoTis, NL), Epidex ${ }^{\mathrm{TM}}$ (DFB Bioscience, CH), and Keragraf ${ }^{\mathrm{TM}}$ (Healthpoint Biotherapeutics, US) obtained regulatory clearances and reached limited industrial distribution, but eventually proved to be industrially non-viable. Another product composed of autologous keratinocytes in a $3 \mathrm{D}$ resorbable polymer fleece matrix, applied with 
fibrin sealant (BioSeed- $S^{\mathrm{TM}}$ ), was brought to the market by BioTissue Technologies AG, Freiburg, Germany [60, 62]. This product also showed good safety and efficacy, but the company filed for insolvency after failing to obtain necessary funding. Hyalograft ${ }^{\mathrm{TM}} 3 \mathrm{D}$ (fibroblasts in hyaluronic acid matrix) combined with Laserskin ${ }^{\mathrm{TM}}$ (keratinocytes on hyaluronic membrane) (Anika Therapeutics, US) were paired autologous products (Tissuetech Autograft system) developed by Fidia Advanced Biopolymers [63]. Although large numbers of patients were treated, only retrospective data are published. The product was not industrialized by Anika. The only bilayered autologous product to be prospectively tested for VLU, built on the PolyActive $^{\mathrm{TM}}$ membrane (HC Implants BV, NL), failed to show substantial benefit. The non-biodegradable synthetic dermal component meant that this would never have been a permanent skin substitute.

Autologous tissue grafts are expected to fail if the wound bed is not ready for engraftment - if it is poorly vascularized, infected, or excessively inflamed. If conditions are proper, autografts should be effective although few clinical trials have been conducted to fully substantiate this accepted belief [1].

\section{ALLOGENEIC CELL APPROACHES}

The industrial failure of engineered autologous tissues for VLU encouraged exploration of allogeneic approaches. The need to perform a biopsy and wait for cells to be expanded ex vivo can be avoided, and the quality, potency, and growth characteristics of the cell banks are independent of the patient. Rigorous screening and qualification of donors, combined with many levels of in vitro testing, make it very unlikely that pathogens would be transmitted to the recipient of these products. Time is available for full testing of adventitious agents and tumor-forming potential. Cell growth and metabolic functional characteristics can be selected, with master cell banks being established from only the best-performing cells. Allogeneic cell products can thus be standardized, and availability is potentially immediate depending on the particular storage and stability characteristics of each product.

Keratinocytes obtained from neonatal foreskin show more rapid growth and a capacity for greater population doublings than keratinocytes from adults. Fetal-derived fibroblasts have recently been tested in VLU, with $62 \%$ healing after up to 31 weeks of treatment [64]. However, the use of fetal tissue does not appear to offer any advantages. Cultured adult keratinocytes can normally be expected to continue dividing for $\sim 30$ days, after which they cannot be stimulated to divide or form clones. Fibroblasts seems to have a longer life expectancy, with various studies showing 90 to 100 days of continuous expansion before replication ceases.

Early clinical reports from academic centers on the effects of allogeneic keratinocyte sheets in ulcer healing were promising, but did not indicate engraftment. Leigh and colleagues reported treating 43 VLU patients with wounds of 3-40 years duration [51], with the expectation that the allogeneic tissue could fully engraft. Multilayered keratinocyte sheets were sutured temporarily to a non-adherent dressing, which was removed following placement. Islands of new epithelium were described as evidence of "clinical take" of the graft, seen in $29 \%$ of cases, while new epithelium generated from the wound edges ( $44 \%$ of cases) was presumed to have been stimulated by growth factors such as epidermal growth factor (EGF) and keratinocyte growth factor (KGF). Cony [65] treated 20 leg ulcers of various etiologies in 16 patients, using trypsinized keratinocytes seeded onto Biobrane ${ }^{\mathrm{TM}}$ (Smith \& Nephew) for 2-3 hours prior to application. A reduction in pain was noted in $80 \%$ of cases, and promotion of granulation tissue was seen in the ulcer bed in $70 \%$ of cases. In 10 patients, epithelialization of $71 \pm 29 \%$ of the ulcer surface was noted at Day 30, but in no case was there any "graft take" in the center of the ulcer. Beele et al. [66] reported complete closure of $62 \%$ of 16 leg ulcers within eight weeks after repeated application of allogeneic multilayered keratinocyte sheets stapled to petrolatum gauze. A mean of three applications were applied. New epithelium was almost exclusively generated from the wound edges. De Luca et al. [67] treated 25 VLUs on 17 patients, healing $15(60 \%)$ with an average of five applications of cryopreserved allogeneic keratinocyte sheets fixed to petrolatum gauze. Strong stimulation of granulation tissue formation was noted, with re-epithelialization occurring mostly from the wound edge. In four wounds islands of new epithelium were noted in the center of the wound, but there was no evidence of even transient "graft take". Lindgren did not obtain the same good results, finding a negative effect on ulcer healing associated with glycerol cryopreservation of keratinocyte sheets [68]. These authors assumed that cryopreservation somehow weakened the cells, resulting in a loss in protein synthesis capacity of at least $50 \%$.

Roseeuw et al. [69] observed that healing in ulcers treated with adult donor keratinocyte sheets on petrolatum gauze occurred predominantly by stimulation of granulation tissue, with wound edge effect seen in every case $(27 / 32,84 \%)$ in which healing activity was observed. With a median time of six weeks, 19/32 (59\%) ulcers healed completely. Although no rejection was observed, DNA analysis revealed that the grafted allogeneic keratinocytes were fully replaced by the patient's own epidermis. Marcusson et al. [70] reported a study of 13 patients with 17 VLUs, treated with multilayer keratinocyte sheets derived from neonatal foreskin cells. Similar to other case series, the sheets were transported on petrolatum gauze. Seventy-six per cent (13/17) of the ulcers healed completely, with an average of five applications of cells.

Academic researchers eventually agreed that allogeneic cells are likely to function by providing growth 


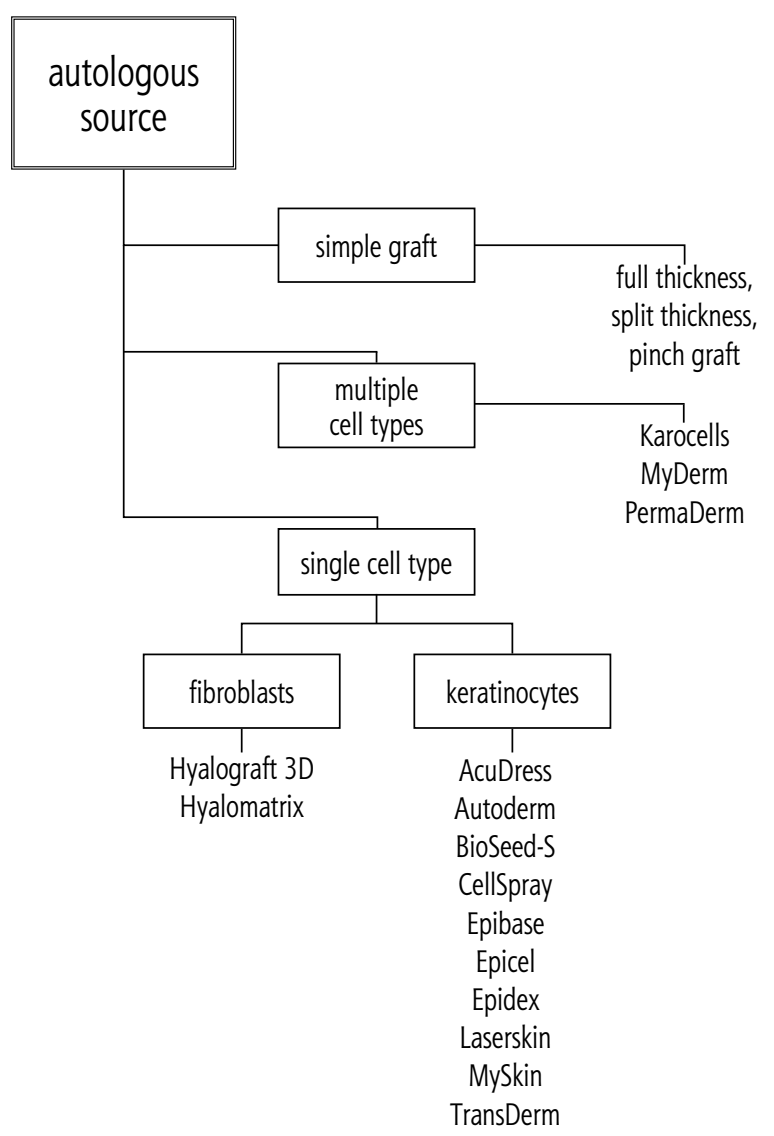

Fig. 1. Summary of autologous cell products tested for efficacy in venous leg ulcers

factors, not by engraftment $[71,72]$. There has been no identification of which growth factors are critical, only general statements that "various growth factors" [73] or "large numbers of growth factors" [74] might explain the beneficial effects. The allogenicity of the materials moved from being a potential concern to an overlooked fact. When pharmaceutical and medical device companies entered the field, allogenicity could not be ignored because regulatory agencies wanted to know about potential immunotoxicity. The need to measure potency also drove some efforts towards understanding which growth factors might be most important, although in some cases it was argued that cell viability was the only appropriate measure of potency.

Despite encouraging academic experiences, no version of allogeneic keratinocytes alone suitable for industrial use has shown clear efficacy in randomized controlled trials. Frozen cultured epidermal allograft $\left(\right.$ Celaderm $^{\mathrm{TM}}$ (Shire Regenerative Medicine, USA)) [75, 76] failed to show efficacy in a 12-week trial involving 40 patients, using weekly or biweekly topical applications of Celaderm $^{\mathrm{TM}}$ to a maximum of four applications compared against standard care. Healing was seen in $8 \%, 27 \%$, and $25 \%$, respectively.

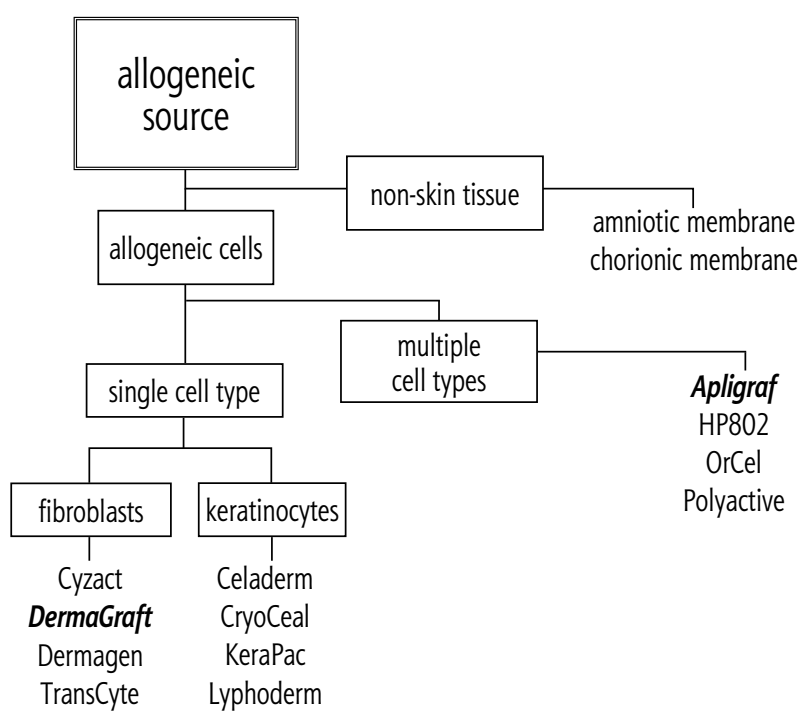

Fig. 2. Summary of allogeneic cell products tested for efficacy in venous leg ulcers. Bold italics indicate the product is commercially available in some markets

An alternative approach to the use of keratinocyte sheets has been the use of fibroblasts embedded in a matrix, with the goal being to provide a dermal template that will stimulate healing. This approach has never been proven to work for VLU. Whether this is due to intrinsic limitations of the approach, or problems with the clinical trial designs, is unknown. Dermagraft ${ }^{\mathrm{TM}}$ was studied by several consecutive companies using different clinical teams (Advanced Tissue Sciences, Advanced Biohealing, Shire Regenerative Medicine), suggesting that the lack of efficacy is intrinsic to the product $[77,78]$. Cyzact ${ }^{\mathrm{TM}}$ (Intercytex, UK) also failed to show efficacy compared to standard care (data not published). An unpublished report on Cyzact from Intercytex Ltd. using chromogenic in situ hybridization (CISH) revealed Y-chromosome in female recipient wounds at $35 \pm 2$ days post treatment, but not at the next time point of 4 months \pm 2 weeks.

Numerous tissue engineering approaches using autologous cells for burn wounds encouraged industrial efforts using both keratinocytes and fibroblasts in recognizable epidermal and dermal compartments. The terms "bilayered skin equivalent" and "skin substitute" came into use, although the latter has generally been abandoned. Combining keratinocytes with fibroblasts may result in more, or different, growth factors [79-81]. Design considerations included handling, stability, and emulation of native structure. Using collagen gels as a type of dermal template for fibroblasts, fibroblast-seeded templates were combined with keratinocyte sheets, even allowing the keratinocytes to differentiate into a mimic of normal epithelium (Apligraf $^{\mathrm{TM}}$, Organogenesis, Massachusetts USA). Of the various products tested, only Apligraf has been found to be somewhat effective in treating VLU $[82,83]$. 
Studies of alloreactivity to Apligraf found no evidence of antibody-mediated or killer cell-mediated rejection [82, 84]. As measured by in situ hybridization for donor cell Y-chromosome, the allogeneic cells persisted in female recipients for only approximately four weeks [85-87]. Reports concerning cell persistence $[85,87]$ were contrary to the published academic experience, but eventually it was understood that histologic constructions are not necessary because the cells begin to die very soon after application [88]. Any barrier or water loss function provided by the engineered tissues is very short lived. Orcel ${ }^{\mathrm{TM}}$ (Ortec International, USA) was another product constructed using both cell types, but it failed to show clear substantial benefit in a 136-patient, randomized, controlled trial, possibly due to protocol design or study conduct.

Given that allogeneic cells do not engraft, the efforts required and limitations imposed in creating an engineered tissue construct seem to be unnecessary [89]. There is potentially a conflict between form and function with the use of cells. In developing a stratified epidermis or bilayered construct, differentiation of keratinocytes creates a stratum corneum (desired form) at the expense of reduced proliferative capacity (function). Whether this affects wound-healing capacity is not clear [90]. Abandoning the concept of engraftment allows new concepts to be introduced, such as growth arrest using mitomycin, $\mathrm{X}$-ray, or gamma irradiation. These methods may give some added protection against persistence of abnormal cells, while at the same time causing cells to shift to a state of injury response.

As Hunyadi et al. [57] did with autologous keratinocytes, an approach can be taken in which the focus is directly on the abilities of the applied cells to influence wound healing. Different cell types can be combined in bioformulations using various ratios and tested at different dose levels, in various carrier media, similar to the development of a standard drug or biologic therapy. This approach offers the potential to adjust several aspects of cell performance prior to delivery. Although no such products have been industrialized, this approach appears to be promising $[45,91,92]$. Unfortunately, the lack of a relevant potency assay caused a loss of reliable quality control and hence consistency in efficacy in confirmatory phase 3 testing. The technical problems of establishing critical quality attributes and in-process controls are not unsolvable, but the final cost of an effective cellular biotherapy must be consistent with the level of benefit that it provides. As with Apligraf, trials with the experimental therapy HP802-247 found no evidence of anti-HLA antibody development [91]. Because these cells are irradiated to prevent replication, their persistence is expected to be shorter than non-irradiated allogeneic cells. As measured by PCR for donor cell Y-chromosome short tandem repeats, cells could be detected for approximately two weeks in acute wounds [93], establishing a potential basis for dose frequency.

\section{FUTURE DIRECTIONS}

Clinical trial evidence to date suggests that allogeneic fibroblasts alone may not be sufficient to promote healing, while keratinocytes alone seem to work only when applied without the types of storage ideally needed for an industrial product. The combination of both cell types appears to hold the greatest promise for ongoing development.

Improving on current allogeneic cell therapy concepts probably requires that the product be understood as a biotherapy, with cells having measurable potency and consistency in manufacturing. The product needs to promote healing or regeneration once the wound environment is amenable, which very likely requires an anti-inflammatory effect. The components of the cell therapy should not exacerbate or add to the inflammatory state of the wound. Delivery to the patient must be as simple and practical as possible, ideally at low temperature or room temperature rather than extreme cold temperatures. The production of cell-based therapies requires a coordinated system of tissue procurement, cell banking, and production, which is still highly manual and dependent upon skilled technicians. The logistics of ordering and delivery must correspond to the shelf life, which may be short once a product reaches the clinic.

As we learn more about the requirements for successful cell therapy, it may be possible to jump ahead to cell lines carrying expression vectors for proteins of special interest (e.g. StrataGraft ${ }^{\mathrm{TM}}$ [Stratatech, Wisconsin USA]) that may boost both the anti-inflammatory and growth-promoting properties of allogeneic cells, albeit with novel concerns over safety.

\section{References}

1. Jones J.E., Nelson E.A., Al-Hity A. Skin grafting for venous leg ulcers. Cochrane Database Syst Rev 2013; CD001737.

2. Gohel M.S., Barwell J.R., Taylor M., Chant T., Foy C., Earnshaw J.J., Heather B.P., Mitchell D.C., Whyman M.R., Poskitt K.R. Long term results of compression therapy alone versus compression plus surgery in chronic venous ulceration (ESCHAR): randomised controlled trial. BMJ 2007; 335: 83-88.

3. O’Donnell T.F. Jr, Lau J. A systematic review of randomized controlled trials of wound dressings for chronic venous ulcer. J Vasc Surg 2006; 44: 1118-1125.

4. van der Veen V.C., van der Wal M.B., van Leeuwen M.C., Ulrich M.M., Middelkoop E. Biological background of dermal substitutes. Burns 2010; 36: 305-321.

5. Böttcher-Haberzeth S., Biedermann T., Reichmann E. Tissue engineering of skin. Burns 2010; 36: 450-460.

6. Shevchenko R.V., James S.L., James S.E. A review of tissue-engineered skin bioconstructs available for skin reconstruction. J R Soc Interface 2010; 7: 229-258.

7. Burnand K.G., Wadoodi A. The physiology and hemodynamics of chronic venous insufficiency of the lower limb. In: Handbook of Venous Disorders: Guidelines of the American Venous Forum. Gloviczki P. (ed.). Hodder Arnold, London 2009; 47-55. 
8. Pappas P.J., Lal B.K., Padberg F.T. Jr, Zickler R.W., Duran W.N. Pathogenesis of varicose veins and cellular pathophysiology of chronic venous insufficiency. In: Handbook of Venous Disorders: Guidelines of the American Venous Forum. Gloviczki P. (ed.). Hodder Arnold, London 2009; 56-69.

9. Smith PD. Update on chronic-venous-insufficiency-induced inflammatory processes. Angiology 2001; 52: S35-S42.

10. Dutra F.F., Bozza M.T. Heme on innate immunity and inflammation. Front Pharmacol 2014; 5: 115.

11. Rosner K., Ross C., Karlsmark T., Petersen A.A., Gottrup F., Vejlsgaard G.L. Immunohistochemical characterization of the cutaneous cellular infiltrate in different areas of chronic leg ulcers. APMIS 1995; 103: 293-299.

12. Simka M. Cellular and molecular mechanisms of venous leg ulcers development - the "puzzle" theory. Int Angiol 2010; 29: 1-19.

13. Abd-El-Aleem S.A., Ferguson M.W., Appleton I., Kairsingh S., Jude E.B., Jones K., McCollum C.N., Ireland G.W. Expression of nitric oxide synthase isoforms and arginase in normal human skin and chronic venous leg ulcers. J Pathol 2000; 191: 434-442.

14. Raffetto J.D. Dermal pathology, cellular biology, and inflammation in chronic venous disease. Thromb Res 2009; 123: S66-S71.

15. Loots M.A., Lamme E.N., Zeegelaar J., Mekkes J.R., Bos J.D., Middelkoop E. Differences in cellular infiltrate and extracellular matrix of chronic diabetic and venous ulcers versus acute wounds. J Invest Dermatol 1998; 111: 850-857.

16. Gatenby R.A., Taylor D.D., Ellison D.J. Identification of a novel cell population in nonhealing wounds in tumors. J Surg Res 1992; 53: 188-194.

17. Sindrilaru A., Peters T., Wieschalka S., Baican C., Baican A., Peter H., Hainzl A., Schatz S., Qi Y., Schlecht A., Weiss J.M., Wlaschek M., Sunderkötter C., Scharffetter-Kochanek K. An unrestrained proinflammatory M1 macrophage population induced by iron impairs wound healing in humans and mice. J Clin Invest 2011; 121: 985-997.

18. Novak M.L., Koh T.J. Macrophage phenotypes during tissue repair. J Leukoc Biol 2013; 93: 875-881.

19. Mosti G., Iabichella M.L., Picerni P., Magliaro A., Mattaliano V. The debridement of hard to heal leg ulcers by means of a new device based on Fluidjet technology. Int Wound J 2005; 2: 307314.

20. Jull A.B., Arroll B., Parag V., Waters J. Pentoxifylline for treating venous leg ulcers. Cochrane Database Syst Rev 2012; 12: CD001733.

21. Streit M., Beleznay Z., Braathen L.R. Topical application of the tumour necrosis factor-alpha antibody infliximab improves healing of chronic wounds. Int Wound J 2006; 3: 171-179.

22. Kirsner RS. Biological agents for chronic wounds. Am J Clin Dermatol 2010; 11 Suppl 1: 23-25.

23. Vin F., Teot L., Meaume S. The healing properties of Promogran in venous leg ulcers. J Wound Care 2002; 11: 335-341.

24. Raffetto J.D. Which dressings reduce inflammation and improve venous leg ulcer healing. Phlebology 2014; 29: 157-164.

25. Ellingsworth L.R., DeLustro F., Brennan J.E., Sawamura S., McPherson J. The human immune response to reconstituted bovine collagen. J Immunol 1986; 136: 877-882.

26. McCoy J.P. Jr, Schade W.J., Siegle R.J., Waldinger T.P., Vanderveen E.E., Swanson N.A. Characterization of the humoral immune response to bovine collagen implants. Arch Dermatol 1985; 121: 990-994.
27. Billingham R.E., Brent L., Medawar P.B., Sparrow E.M. Quantitative studies on tissue transplantation immunity. I. The survival times of skin homografts exchanged between members of different inbred strains of mice. Proc R Soc Lond B Biol Sci 1954; 143: 43-58.

28. Dvorak H.F., Mihm M.C. Jr, Dvorak A.M., Barnes B.A., Manseau E.J., Galli S.J. Rejection of first-set skin allografts in man. the microvasculature is the critical target of the immune response. J Exp Med 1979; 150: 322-337.

29. Phillips T.J., Kehinde O., Green H., Gilchrest B.A. Treatment of skin ulcers with cultured epidermal allografts. J Am Acad Dermatol 1989; 21: 191-199.

30. van der Merwe A.E., Mattheyse F.J., Bedford M., van Helden P.D., Rossouw D.J. Allografted keratinocytes used to accelerate the treatment of burn wounds are replaced by recipient cells. Burns 1990; 16: 193-197.

31. Kawai K., Ikarashi Y., Tomiyama K., Matsumoto Y., Fujiwara M. Rejection of cultured keratinocyte allografts in presensitized mice. Transplantation 1993; 56: 265-269.

32. Kern A., Liu K., Mansbridge J. Modification of fibroblast gamma-interferon responses by extracellular matrix. J Invest Dermatol 2001; 117: 112-118.

33. Thivolet J., Faure M., Demidem A., Mauduit G. Long-term survival and immunological tolerance of human epidermal allografts produced in culture. Transplantation 1986; 42: 274-280.

34. Quatresooz P., Henry F., Paquet P., Pierard-Franchimont C., Harding K., Pierard G.E. Deciphering the impaired cytokine cascades in chronic leg ulcers (review). Int J Mol Med 2003; 11: 411-418.

35. Chen W., Jin W., Hardegen N., Lei K.J., Li L., Marinos N., McGrady G., Wahl S.M. Conversion of peripheral CD4+CD25naive $\mathrm{T}$ cells to $\mathrm{CD} 4+\mathrm{CD} 25+$ regulatory $\mathrm{T}$ cells by TGF-beta induction of transcription factor Foxp3. J Exp Med 2003; 198 : 1875-1886.

36. Kuklina E.M. Molecular mechanisms of T-cell anergy. Biochemistry (Mosc) 2013; 78: 144-156.

37. Gwyer Findlay E., Hussell T. Macrophage-mediated inflammation and disease: a focus on the lung. Mediators Inflamm 2012; 2012: 140937.

38. Da Costa R.M., Ribeiro Jesus F.M., Aniceto C., Mendes M. Randomized, double-blind, placebo-controlled, dose- ranging study of granulocyte-macrophage colony stimulating factor in patients with chronic venous leg ulcers. Wound Repair Regen 1999; 7: 17-25.

39. Novak M.L., Thorp E.B. Shedding light on impaired efferocytosis and nonresolving inflammation. Circ Res 2013; 113: 9-12.

40. Li F., Huang Q., Chen J., Peng Y., Roop D.R., Bedford J.S., Li C.Y. Apoptotic cells activate the "phoenix rising" pathway to promote wound healing and tissue regeneration. Sci Signal 2010; 3: ra13.

41. Kroemer A., Xiao X., Degauque N., Edtinger K., Wei H., Demirci G., Li X.C. The Innate NK Cells, Allograft Rejection, and a Key Role for IL-15. J Immunol 2008; 180: 7818-7826.

42. Flis V., Matela J., Miksić K., Pavlović M., Mrdja B. Role of arteriovenous shunting in venous ulcers-therapeutic implications. Wien Klin Wochenschr 2001; 113: 14-17.

43. Wall I.B., Moseley R., Baird D.M., Kipling D., Giles P., Laffafian I., Price P.E., Thomas D.W., Stephens P. Fibroblast dysfunction is a key factor in the non-healing of chronic venous leg ulcers. J Invest Dermatol 2008; 128: 2526-2540. 
44. O’Meara S., Cullum N.A., Nelson E.A. Compression for venous leg ulcers. Cochrane Database Syst Rev 2009; CD000265.

45. Lantis J.C. 2nd, Marston W.A., Farber A., Kirsner R.S., Zhang Y., Lee T.D., Cargill D.I., Slade H.B. The influence of patient and wound variables on healing of venous leg ulcers in a randomized controlled trial of growth-arrested allogeneic keratinocytes and fibroblasts. J Vasc Surg 2013; 58: 433-439.

46. Brem H., Stojadinovic O., Diegelmann R.F., Entero H., Lee B., Pastar I., Golinko M., Rosenberg H., Tomic-Canic M. Molecular markers in patients with chronic wounds to guide surgical debridement. Mol Med 2007; 13: 30-39.

47. Ljunggren C.C. On the safe survival of skin epithelial cells outside of the human organism with special reference to skin transplantation. Nordiskt Medicinskt Arkiv 1898; 31: 1-10.

48. Billingham R.E., Reynolds J. Transplantation studies on sheets of pure epidermal epithelium and on epidermal cell suspensions. Br J Plast Surg 1952; 5: 25-36.

49. Rheinwald J.G., Green H. Serial cultivation of strains of human epidermal keratinocytes: the formation of keratinizing colonies from single cells. Cell 1975; 6: 331-343.

50. Hefton J.M., Caldwell D., Biozes D.G., Balin A.K., Carter D.M. Grafting of skin ulcers with cultured autologous epidermal cells. J Am Acad Dermatol 1986; 14: 399-405.

51. Leigh I.M., Purkis P.E., Navsaria H.A., Phillips T.J. Treatment of chronic venous ulcers with sheets of cultured allogenic keratinocytes. Br J Dermatol 1987; 117: 591-597.

52. Yannas I.V., Burke J.F., Gordon P.L., Huang C., Rubenstein R.H. Design of an artificial skin. II. Control of chemical composition. J Biomed Mater Res 1980; 14: 107-132.

53. Pye R.J. Cultured keratinocytes as biological wound dressings. Eye (Lond) 1988; 2: 172-178.

54. Schulz J.T. $3^{\text {rd }}$, Tompkins R.G., Burke J.F. Artificial skin. Annu Rev Med 2000; 51: 231-244.

55. Bell E., Sher S., Hull B., Merrill C., Rosen S., Chamson A., Asselineau D., Dubertret L., Coulomb B., Lapiere C., Nusgens B., Neveux Y. The reconstitution of living skin. J Invest Dermatol 1983; 81: 2s-10s.

56. Phillips T.J., Gilchrest B.A. Cultured epidermal grafts in the treatment of leg ulcers. Adv Dermatol 1990; 5: 33-48.

57. Hunyadi J., Farkas B., Bertényi C., Oláh J., Dobozy A. Keratinocyte grafting: covering of skin defects by separated autologous keratinocytes in a fibrin net. J Invest Dermatol 1987; 89: 119120.

58. Tausche A.K., Skaria M., Böhlen L., Liebold K., Hafner J., Friedlein H., Meurer M., Goedkoop R.J., Wollina U., Salomon D., Hunziker T. An autologous epidermal equivalent tissue-engineered from follicular outer root sheath keratinocytes is as effective as split-thickness skin autograft in recalcitrant vascular leg ulcers. Wound Repair Regen 2003; 11: 248-252.

59. Tausche A.K., Salomon D., Wollina U., Meurer M., Goedkoop R., Hunziker T. Epidex: A novel treatment for recalcitrant vascular leg ulcers, 6-month follow-up results. Wound Repair Regen 2003; 11: A19.

60. Vanscheidt W., Ukat A., Horak V., Brüning H., Hunyadi J., Pavlicek R., Emter M., Hartmann A., Bende J., Zwingers T., Ermuth T., Eberhardt R. Treatment of recalcitrant venous leg ulcers with autologous keratinocytes in fibrin sealant: a multinational randomized controlled clinical trial. Wound Repair Regen 2007; 15: 308-315.

61. Wille J.J., Burdge J.J., Pitttelkow M.R. Rapid healing of chronic venous stasis leg ulcers treated by the application of a nov- el serum-free cultured autologous epidermis. Wound Repair Regen 2011; 19: 464-474.

62. Johnsen S., Ermuth T., Tanczos E., Bannasch H., Horch R.E., Zschocke I., Peschen M., Schöpf E., Vanscheidt W., Augustin M. Treatment of therapy-refractive ulcera cruris of various origins with autologous keratinocytes in fibrin sealant. Vasa 2005; 34: 25-29.

63. Uccioli L.; TissueTech Autograph System Italian Study Group. A clinical investigation on the characteristics and outcomes of treating chronic lower extremity wounds using the tissuetech autograft system. Int J Low Extrem Wounds 2003; 2: 140-151.

64. Ramelet A.A., Hirt-Burri N., Raffoul W., Scaletta C., Pioletti D.P., Offord E., Mansourian R., Applegate L.A. Chronic wound healing by fetal cell therapy may be explained by differential gene profiling observed in fetal versus old skin cells. Exp Gerontol 2009; 44: 208-218.

65. Cony M., Donatien P., Beylot C., Géniaux M., Maleville J., Bézian J.H., Taïeb A. Treatment of leg ulcers with an allogeneic cultured-keratinocyte-collagen dressing. Clin Exp Dermatol 1990; 15: 410-414.

66. Beele H., Naeyaert J.M., Goeteyn M., De Mil M., Kint A. Repeated cultured epidermal allografts in the treatment of chronic leg ulcers of various origins. Dermatologica 1991; 183: 31-35.

67. De Luca M., Albanese E., Cancedda R., Viacava A., Faggioni A., Zambruno G., Giannetti A. Treatment of leg ulcers with cryopreserved allogeneic cultured epithelium. A multicenter study. Arch Dermatol 1992; 128: 633-638.

68. Lindgren C., Marcusson J.A., Toftgård R. Treatment of venous leg ulcers with cryopreserved cultured allogeneic keratinocytes: a prospective open controlled study. Br J Dermatol 1998; 139 : 271-275.

69. Roseeuw D.I., De Coninck A., Lissens W., Kets E., Liebaers I., Vercruysse A., Vandenberghe Y. Allogeneic cultured epidermal grafts heal chronic ulcers although they do not remain as proved by DNA analysis. J Dermatol Sci 1990; 1: 245-252.

70. Marcusson J.A., Lindgren C., Berghard A., Toftgård R. Allogeneic cultured keratinocytes in the treatment of leg ulcers. A pilot study. Acta Derm Venereol 1992; 72: 61-64.

71. Hancock K., Leigh I.M. Cultured keratinocytes and keratinocyte grafts. BMJ 1989; 299: 1179-1180.

72. Beele H., Naeyaert J.M., Monstrey S., Kint A. Ulcers in pretibial epidermolysis bullosa. Grafting with autologous meshed split-thickness skin and allogeneic cultured keratinocytes. Arch Dermatol 1995; 131: 990-992.

73. Siedler S., Schuller-Petrovic S. Allogenic keratinocytes suspended in human fibrin glue used for wound healing support in chronic leg ulcers. Arch Dermatol 2000; 136: 676-678.

74. Morton L.M., Phillips T.J. Wound healing update. Semin Cutan Med Surg 2012; 31: 33-37.

75. Bolivar-Flores J., Poumian E., Marsch-Moreno M., Montes de O.G., Kuri-Harcuch W. Use of cultured human epidermal keratinocytes for allografting burns and conditions for temporary banking of the cultured allografts. Burns 1990; 16: 3-8.

76. Bolívar-Flores Y.J., Kuri-Harcuch W. Frozen allogeneic human epidermal cultured sheets for the cure of complicated leg ulcers. Dermatol Surg 1999; 25: 610-617.

77. Omar A.A., Mavor A.I., Jones A.M., Homer-Vanniasinkam S. Treatment of venous leg ulcers with Dermagraft. Eur J Vasc Endovasc Surg 2004; 27: 666-672.

78. Harding K., Sumner M., Cardinal M. A prospective, multicentre, randomised controlled study of human fibroblast-de- 
rived dermal substitute (Dermagraft) in patients with venous leg ulcers. Int Wound J 2013; 10: 132-137.

79. Spiekstra S.W., Breetveld M., Rustemeyer T., Scheper R.J., Gibbs S. Wound-healing factors secreted by epidermal keratinocytes and dermal fibroblasts in skin substitutes. Wound Repair Regen 2007; 15: 708-717.

80. Maas-Szabowski N., Shimotoyodome A., Fusenig N.E. Keratinocyte growth regulation in fibroblast cocultures via a double paracrine mechanism. J Cell Sci 1999; 112: 1843-1853.

81. Bader R.A., Kao W.J. Modulation of the keratinocyte-fibroblast paracrine relationship with gelatin-based semi-interpenetrating networks containing bioactive factors for wound repair. J Biomater Sci Polym Ed 2009; 20: 1005-1030.

82. Falanga V., Margolis D., Alvarez O., Auletta M., Maggiacomo F., Altman M., Jensen J., Sabolinski M., Hardin-Young J. Rapid healing of venous ulcers and lack of clinical rejection with an allogeneic cultured human skin equivalent. Human Skin Equivalent Investigators Group. Arch Dermatol 1998; 134: 293-300.

83. Falanga V., Sabolinski M. A bilayered living skin construct (APLIGRAF) accelerates complete closure of hard-to-heal venous ulcers. Wound Repair Regen 1999; 7: 201-207.

84. Badiavas E.V., Paquette D., Carson P., Falanga V. Human chronic wounds treated with bioengineered skin: histologic evidence of host-graft interactions. J Am Acad Dermatol 2002; 46: 524530.

85. Phillips T.J., Manzoor J., Rojas A., Isaacs C., Carson P., Sabolinski M., Young J., Falanga V. The longevity of a bilayered skin substitute after application to venous ulcers. Arch Dermatol 2002; 138: 1079-1081.

86. Griffiths M., Ojeh N., Livingstone R., Price R., Navsaria H. Survival of Apligraf in acute human wounds. Tissue Eng 2004; 10: 1180-1195.

87. Hu S., Kirsner R.S., Falanga V., Phillips T., Eaglstein W.H. Evaluation of Apligraf persistence and basement membrane restoration in donor site wounds: a pilot study. Wound Repair Regen 2006; 14: 427-433.

88. Brem H., Young J., Tomic-Canic M., Isaacs C., Ehrlich H.P. Clinical efficacy and mechanism of bilayered living human skin equivalent (HSE) in treatment of diabetic foot ulcers. Surg Technol Int 2003; 11: 23-31.

89. Mol M.A., Nanninga P.B., van Eendenburg J.P., Westerhof W., Mekkes J.R., van Ginkel C.J. Grafting of venous leg ulcers. An intraindividual comparison between cultured skin equivalents and full-thickness skin punch grafts. J Am Acad Dermatol 1991; 24: 77-82.

90. Fredriksson C., Kratz G., Huss F. Transplantation of cultured human keratinocytes in single cell suspension: a comparative in vitro study of different application techniques. Burns 2008; 34: 212-219.

91. Kirsner R.S., Marston W.A., Snyder R.J., Lee T.D., Cargill D.I., Slade H.B. A multicentre randomised dosing trial of spray-applied cell therapy with human allogeneic fibroblasts and keratinocytes for the treatment of chronic venous leg ulcers. Lancet 2012; 380: 977-985.

92. Kirsner R.S., Marston W.A., Snyder R.J., Lee T.D., Cargill D.I., Zhang Y., Dickerson J.E. Jr, Slade HB. Durability of healing from spray-applied cell therapy with human allogeneic fibroblasts and keratinocytes for the treatment of chronic venous leg ulcers: A 6-month follow-up. Wound Repair Regen 2013; 21: 682-687.
93. Dickerson J.E., Planz J.V., Reece B.T., Weedon K.A., Kirkpatrick S.D., Slade H.B. Cell persistence of allogeneic keratinocytes and fibroblasts applied in a fibrin matrix to acute, full thickness wounds. Cell Med 2013; 4: 149-152. 